\title{
Problems of Strategic Development of Regions of Ukraine Using Smart Specialization Concept
}

\author{
Svitlana Shults* \\ Department of regional \\ economic policy \\ State Institution "Institute of Regional \\ Research named after M.I. Dolishniy of \\ the NAS of Ukraine" \\ Lviv, Ukraine \\ e-mail: swetshul@i.ua ORCID \\ https://orcid.org/0000-0002-5603-5603
}

\author{
Maksym Maksymchuk \\ Senior Researcher \\ State Institution "Institute of Regional \\ Research named after M.I. Dolishniy of \\ the NAS of Ukraine" \\ Lviv, Ukraine \\ e-mail: regionmak@gmail.com \\ ORCID https://orcid.org/0000-0001- \\ 5177-539X
}

Liliya Marynchak

Finance Department

Ivano-Frankivsk National Technical

University oil and gas

Ivano-Frankivsk, Ukraine

e-mail: lmarynchak@yahoo.com

ORCID https://orcid.org/0000-0001-

8422-8114

\author{
Liliia Simkiv \\ Department of Theory of Economics \\ and management \\ Ivano-Frankivsk National Technical \\ University oil and gas \\ Ivano-Frankivsk, Ukraine \\ e-mail: simkivlilya@gmail.com \\ ORCID \\ https://orcid.org/0000-0001-8270-237X
}

\begin{abstract}
The theoretical and methodological nature of strategic development on the basis of smart specialization is investigated and its role in ensuring the economic growth of regions and increasing the effectiveness of regional policy is substantiated. Methodical approaches are proposed to identify the types of economic activity that will be developed in accordance with the principles of smart specialization and which can be considered as strategic goals of regional strategies. The approbation of these approaches in the analysis of production, innovation, export and human resources in the context of economic activities on example of Lviv region allows to determine the strategic priorities of the region's development using a concept of smart specialization. The result of the analysis is to identify problems of implementation of smart specialization concept in the development of strategies for Ukrainian regions and proposals for their solution.
\end{abstract}

Keywords- region, strategy, smart specialization, strategic goals, innovative economic activities, inclusive growth, competitive advantages.

\section{INTRODUCTION}

The current stage of implementation of regional policy in Ukraine is connected with a new stage of development of regional strategies, within which it is envisaged to determine strategic priorities for the development of regions. According to the current regulatory framework on strategic planning issues, in particular, the methods of developing, monitoring and evaluating the effectiveness of the implementation of regional development strategies, the choice of strategic goals for regional development should be based on three methodological approaches: integration, which involves a combination of territorial and administrative components of national regional policy; gender - based on the principle of gender equality with the involvement of representatives of regional development, which allow to take into account the interests of different population groups in different spheres of life at the regional level; smart specialization, which provides for a welldefined definition of regional development entities within the framework of a regional strategy of specific strategic goals and objectives for the development of economic activities that have innovative potential, can be considered as a competitive advantage of the region and contribute to the transformation of all sectors of the economy into more effective [1]

While highlighting the issue of choosing strategic priorities for regional development, we would point out that in the EU Member States smart specialization strategies (RIS3) are an important part of the strategic direction of EU spending on regional development, and their availability is a prerequisite for supporting regional innovation, reducing disproportions between regions and strengthening economic, social and territorial cohesion. The concept of smart specialization has been widely implemented in recent years by European Union countries and has become central to European policy. Smart specialization is now considered as a tool for improving the management of the socio-economic development of regions and setting strategic goals for their development, which will contribute to the renewal of specialization of their economy by developing innovative and environmentally friendly non-traditional types of economic activity and start-up industry to create a new innovative business, as well as the modernization of traditional sectors of the regions. In this context, an important scientific task is the adaptation and improvement of existing methodological approaches to the implementation of long-term planning for the development of each of the regions in order to determine the possible prospects for structural transformation of their economy, taking into account regional features, territorial resource 
potential, opportunities for the use of technological and institutional innovations, active innovation trends in the interpersonal, interregional and international dimension. The application of this approach will contribute to obtaining a synergistic effect for human development and improving the quality of life of the Ukrainian population. The development of smart specialization strategies should also be seen as a tool for improving regional policy effectiveness.

\section{ANALYSIS OF MAIN ACHIEVEMENTS}

A number of foreign and Ukrainian scientists point out the positive effect of the introduction of smart specialization concept into the strategic planning of regional development. Thus, M. Benner points out that the development of smart specialization strategies will increase the effectiveness of regional policy and stimulate innovative processes in business in European regions. By conducting empirical studies of institutional changes in entrepreneurial activity in the case of several regions (Lower Austria, South Tyrol (Italy), Slovenia and Croatia), the author assesses the effects of such policies and their impact on EU cohesion policy beyond 2020 [2].

Therefore, the implementation of the smart approach in the field of strategic planning of regional development enhances the possibilities not only to identify priority economic activities for certain regions, but also to analyze the effectiveness of regional policy. In this context, J. Glückler, R. Lenz proposed a research agenda on the systematic involvement of institutions in the analysis of regional policy effectiveness [3].

Noting the important place of the idea of smart specialization in the discourse of EU regional policy, $\mathrm{M}$. Benner argues that it becomes the ideological basis for the functioning of the EU structural funds. Based on the basic principles of the evolutionary economy and guided by the ideas of the entrepreneurial process, the strategy of smart specialization opens new vectors of regional development [4].

In explaining the particularities of implementing the RIS3 policy agenda, $H$. Kroll notes that innovative institutional arrangements for regional governance are no less important than the technical and economic potential of the territories. In his article, a scientist demonstrates how Southern Europe has profited from new practices, while Eastern Europe has had to invest heavily to change existing management procedures and practices [5].

Considering the concept of smart specialization as one of the platforms for reconciling the activities of several entities to stimulate regional economic development, M. Sotarauta argues that the necessary condition for the development of truly transformative strategies of smart specialization is close cooperation between objects and entities of regional development. In this way, different interests will be reconciled in European regions and new forms of leadership will be introduced [6].

Emphasizing the difference between the methodological approach to identifying strategic priorities for regional development on the basis of smart specialization from the traditional, R. Ortega Argiles, P. McCann notes that this approach involves moving away from stimulating industries or sectors exclusively to support a greater level of activity, such as technologies or technological complexes, specific (unique) capabilities, natural assets, etc. In these circumstances, when setting strategic priorities, the main focus is on the competitive advantages of the region and its innovation potential, the concentration of state resources on priorities and needs for innovation development, the intensification of private investment in research and the involvement of key stakeholders and development stakeholders [7].

D. D'Adda, E. Guzzini emphasize that identifying technological areas within the framework of the Smart Specialization Strategy (S3), which have better technological capabilities, contributes to the smart specialization and diversification of the regional economy. Empirical studies conducted by scientists on the example of the Italian regions have proved that their real innovative capabilities depend on their patent activity [8].

The success of Smart specialization in regions strategies is linked to the problem of inter-regional disproportions, the lack of preconditions for implementing innovative processes in the local economy. This is the focus of R. Capello, $\mathrm{H}$. Kroll [9]. Discussions on the role of universities and other institutions of knowledge as drivers of reasonable specialization in all regions, including the regions with different scientific and innovative capabilities are led by $\mathrm{P}$. Vallance, J. Blažek, J. Edwards, V. Květoň [10]. Scientists emphasize that in the context of the formation and implementation of Smart specialization strategies in Europe, the role of universities in regional innovation systems is increasing.

The analysis of scientific publications on the outlined issues shows that the ideology of the strategy of smart specialization of regions is intended to solve a number of issues - from a strategic vision of the development of regions to enhancing the role of innovation and their carriers in using the competitive advantages of regions. This necessitates empirical research to determine the competitive advantages of the regions in the context of the development of certain types of economic activity and to evaluate the existing prerequisites for the innovative development of the regions.

The purpose of this article is to extend the theoretical and methodological foundations of defining the strategic goals of the region's development based on the concept of smart specialization and testing them with the example of the Lviv region.

\section{STUDY METHODS AND RESULTS}

In the development of new regional strategies in the Ukrainian realities, it is advisable to focus on the principles and ideology of the concept of smart specialization, since the strategic goals defined on this methodological basis should be considered as "growth points" of the economy of the regions, which by their development will create conditions for activating the process of using their own innovative potential and will encourage other less innovative economic activities to contribute to the economic growth of the region. It is very important for the Ukrainian regions to define strategic goals that would take into account the possibilities of innovative modernization of traditional 
sectors of the economy by achieving higher added value, exploring new market niches and leveraging breakthrough innovations in both manufacturing and services.

In addition to developing regional development strategies on the basis of smart specialization, Ukraine has also implemented pilot projects on the implementation of smart specialization in the framework of regional development strategy. These projects have been implemented in three regions (Kharkiv, Transcarpathian and Cherkasy oblasts), which have already joined the European Smart Specialization Platform that provides methodological materials and lessons from the experience of formulating strategies based on the smart approach, providing training and providing access to relevant data and facilitates the possibility of attracting international investors to the development of the region [11].

Comparison with other regions should be used to analyze the depth of economic specialization of a region. In addition, in order to identify the level of specialization for a particular type of economic activity, it is advisable to evaluate its share in the structure of the GVA of the region.

The assessment of the innovation, export and human resources of the region in terms of individual economic activities is very important in this analysis. This approach will help to identify opportunities for structural transformation and diversification of the region's economy and to identify its competitive advantages in the international and domestic markets. In addition, conducting such an analysis on the example of a specific region will not only identify strategic priorities for the development of one of the regions of Western Ukraine, but also identify the specifics and problems of implementing the concept of smart specialization in the development of regional strategies [12].

The region selected for the analysis is characterized by a sufficiently developed economic potential not only in the Western region, but also in the country as a whole. The structure of its economy presents traditional for the region economic activities and industries that actively use innovation. Analyzing the structure of economy of Lviv region by the volume of sold products and the indicator of the employed population (Figure 1) we conclude that the largest volumes of sold products in the region are given by the consolidated industry $(\mathrm{B}+\mathrm{C}+\mathrm{E}+\mathrm{D})$ and wholesale and retail trade and repair of motor transport vehicles and motorcycles $(\mathrm{G})$.

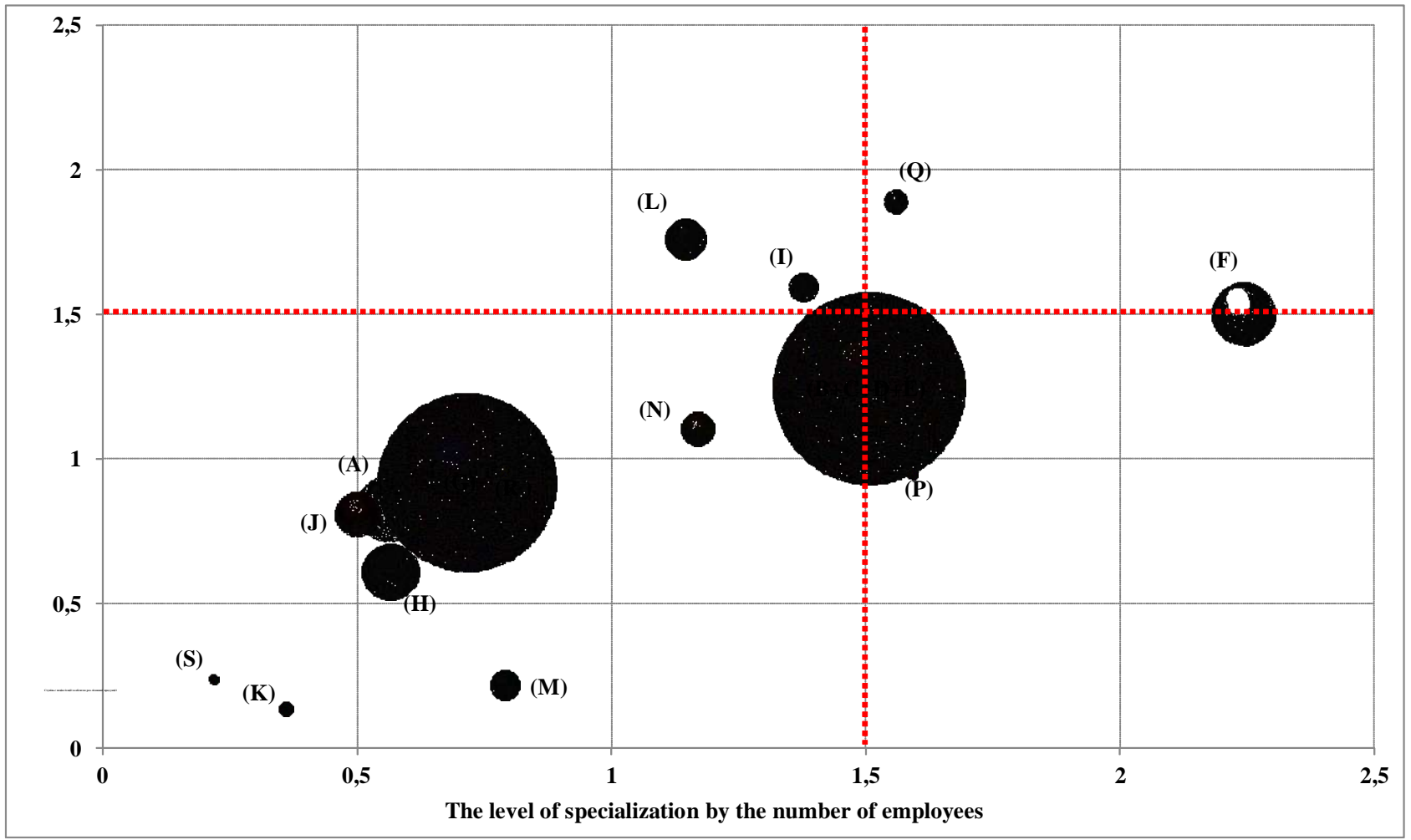

Fig. 1. Structure of economy of Lviv region by types of economic activity (sections) in $2017 *$

\footnotetext{
* The letters in the illustration indicate: (A) - Agriculture, forestry and fisheries; $(\mathrm{B}+\mathrm{C}+\mathrm{E}+\mathrm{D})$ - Industry; (F) - Construction; (G) - Wholesale and retail trade; repair of motor vehicles and motorcycles; $(\mathrm{H})$ - Transport, warehousing, postal and courier activities; (I) - Temporary accommodation and catering; (J) - Information and telecommunications; (K) - Financial and insurance activities; (L) - Real estate activities; (M) - Professional, scientific and technical activities; (N) - Administrative and support service activities; (P) - Education; (Q) - Health care and social assistance; (R) - Arts, sports, entertainment and recreation; (S) - Provision of other services.
}

The third and fourth places, respectively, occupy agriculture, forestry and fisheries (A) and construction (F). That is, the region is characterized by a "traditional" structure of the economy of industrial-agricultural type with significant influence of the trade component. Instead, if we analyze the structure of the economy of Lviv region, based 
on the indicators of the degree of specialization in terms of output and employment ( $\mathrm{Y}$ and $\mathrm{X}$ axes, respectively), we will see that none of the dominant economic activities in the region exceeds the specialization indicator of 1.5. The only industry that falls into this sample is health care and social assistance (Q) is also approaching construction (F). Industries that we can associate with smart specialization information and telecommunications $(\mathrm{J})$, professional, scientific and technical activities (M), financial and insurance activities $(\mathrm{K})$ do not have a level of specialization that is at least one. This may indicate that the region has good potential for increasing the level of smart specialization, provided that national and regional authorities carry out innovative and regional policies aimed at expanding the smart specialization sector.

If we consider the specialization of the region by type of industrial activity (Figure 2), we note that the three types of industrial activity have a degree of specialization with respect to Ukrainian indicators greater than 1.5. These are textile production, production of clothing, leather, leather goods and other materials; manufacture of wood products, paper and printing activities; mechanical engineering (manufacture of motor vehicles, trailers and semi-trailers and other vehicles).

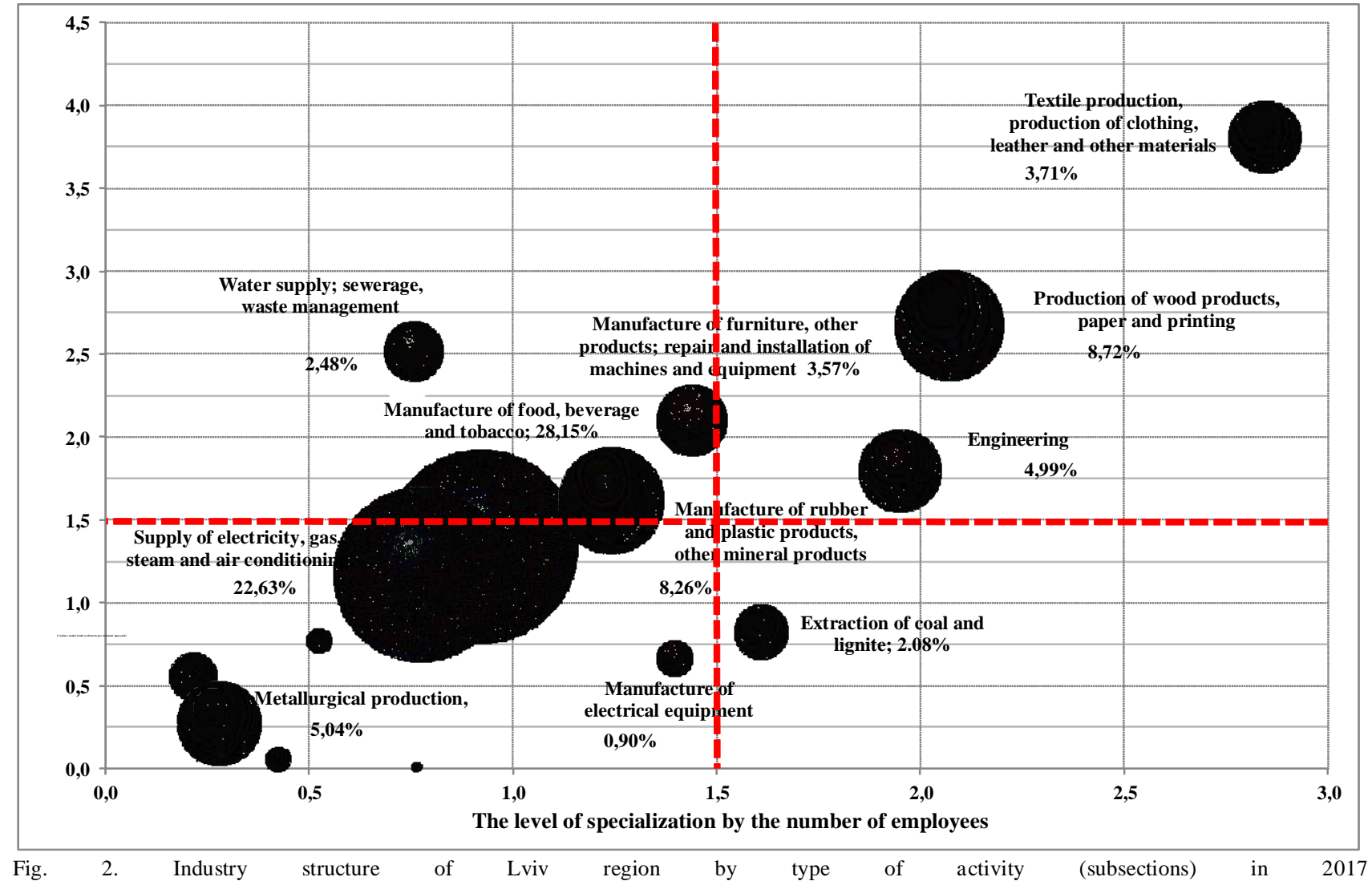

Very close to the level 1.5 there is such kind of industrial activity as manufacture of furniture, other products; repair and installation of machines and equipment. Other industries have a degree of specialization lower than 1.5. It is noteworthy that the largest industries, including food, beverages and tobacco, as well as the supply of electricity, gas, steam and air-conditioning, which together produce almost half of the industry's output, have a specialization rate that practically does not exceed one. An interesting situation in the region is with such a variety of mechanical

The bulk of manufactured finished products are produced here by business entities that work on tolling raw materials and only carry out assembly of production units. Instead, if we consider the growth rates of the industrial sector of Lviv region by type of economic activity (Figure 3 ), the highest levels of specialization show such industries as: mining of coal and brown coal; mechanical engineering and production of motor vehicles, trailers and semi-trailers and other vehicles; mechanical engineering.
Such a significant gap in the coal and brown coal industry can be explained by the processes taking place in the east of Ukraine, since a significant part of the territories that made a significant contribution to the coal industry were in the area of ostilities and temporary occupation by the Russian Federation. A similar situation has arisen with metallurgical production, production of finished metal products.

Particular attention in shaping the strategic support for the socio-economic development of the region should pay attention to such industries as the production of basic pharmaceutical products, as well as to the sub-sector of mechanical engineering, such as the manufacture of computers, electronic and optical products.

The more positive situation was with the export specialization of the Lviv region when compared by groups of goods with Ukraine (Figure 4). 


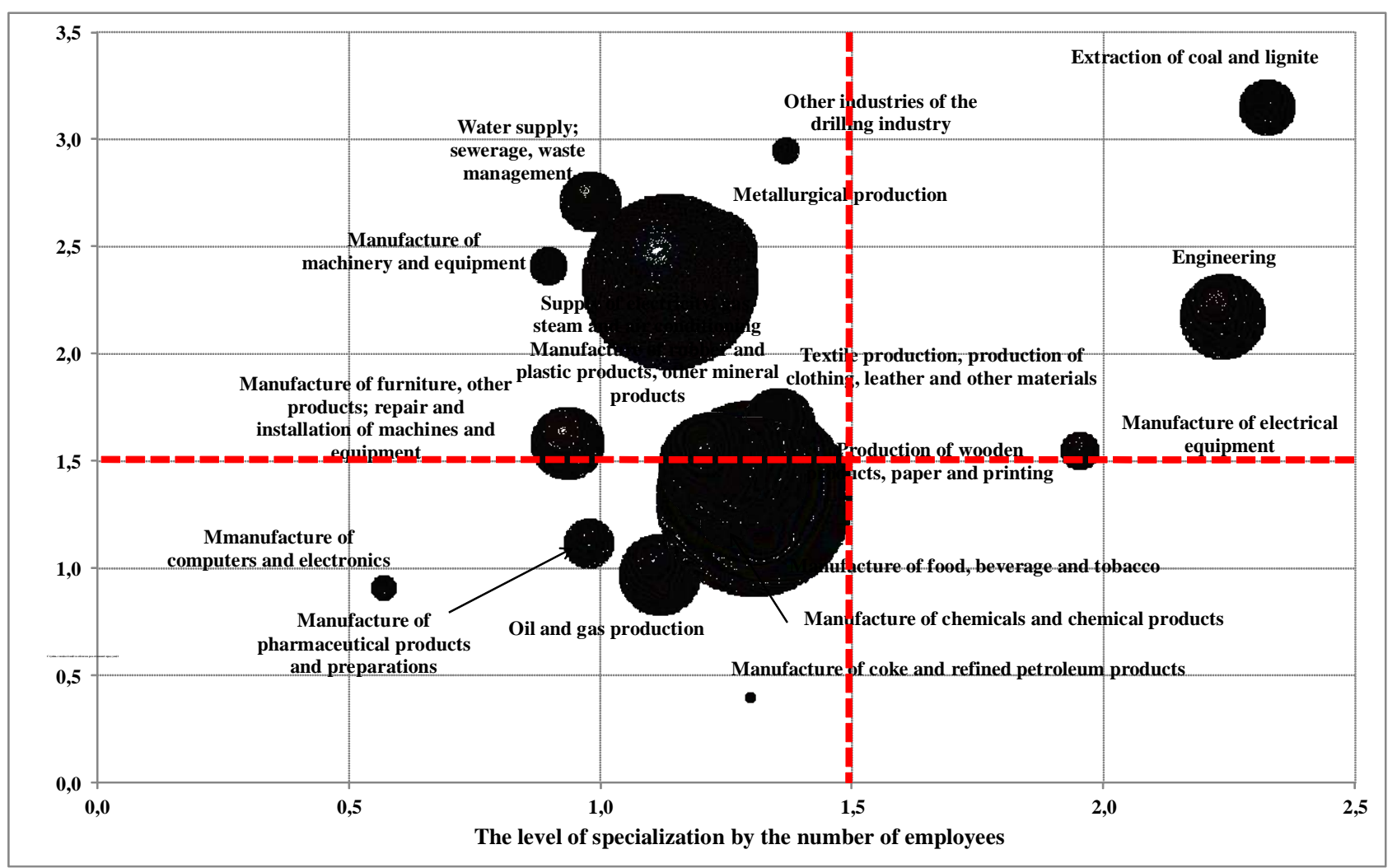

Fig. 3. Growth rates of industry in Lviv region by type of economic activity (subsections) in 2017

The results of a comparative analysis of the level of specialization of services in Lviv region show that strong clusters are formed in the region in the field of transport, programming and provision of information services, as well as tourism and recreation. In addition, a significant role in the service sector is occupied by the health and social assistance cluster, the postal and administrative services cluster. But components such as education, telecommunications, publishing and printing are important for the smart specialization of the region.

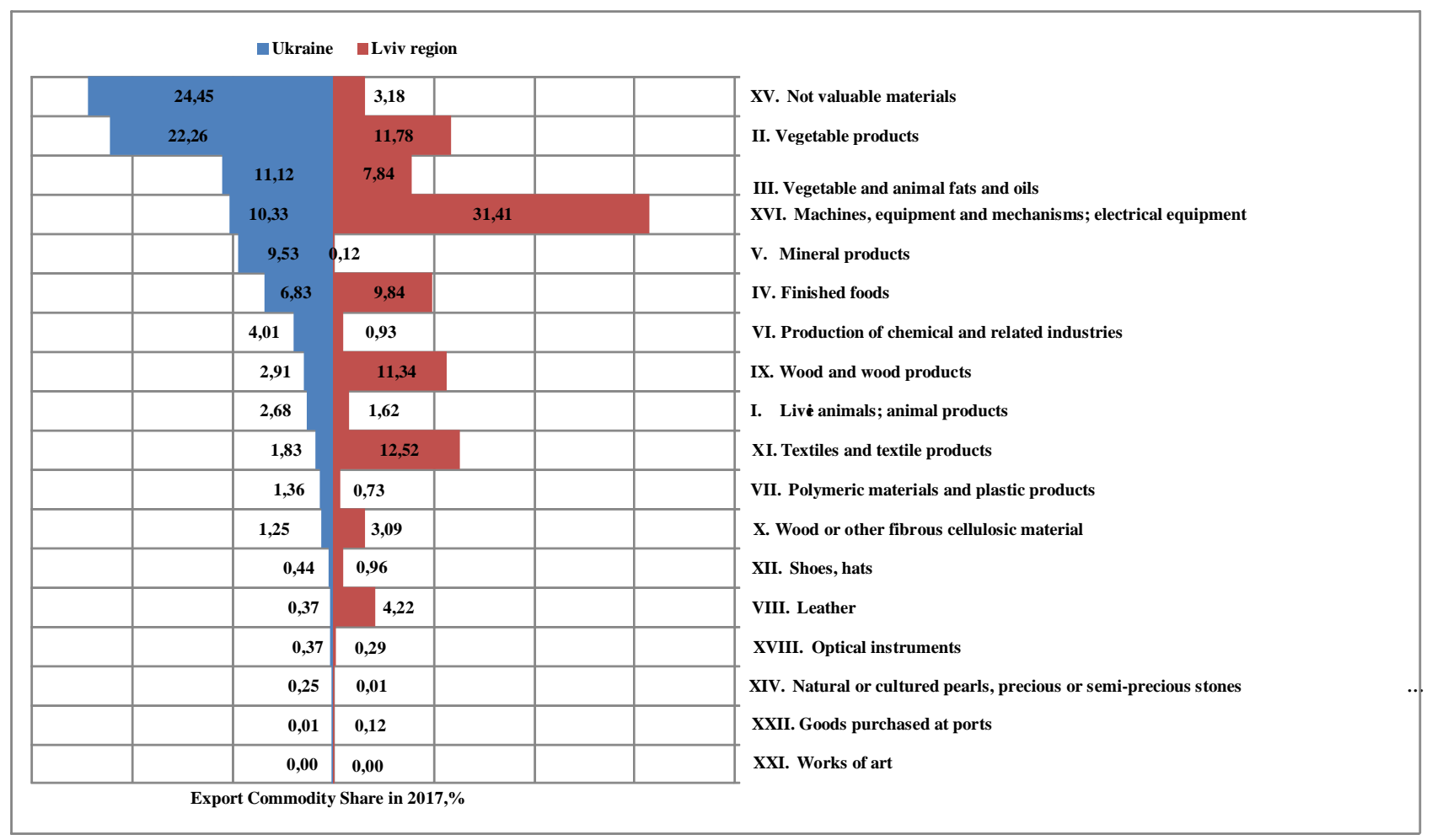

Fig. 4. Comparative structure of exports of Ukraine and Lviv region by consolidated product groups in 2017 
This state of affairs requires regulatory intervention by state authorities at both national and regional levels, as it reduces the intellectual and innovative potential of the region's economy, promotes the outflow of highly qualified personnel from the region (abroad and in the metropolitan region), and reduces the educational level of staff economy of the region, leads to imbalances in the formation of the regional structure of the economy of the state.

Based on the above analysis and selection of prerequisites of formation, we can formulate the previous priorities of smart specialization of the economy of the studied region (Table 1).

TABLE I. PRIORITIES OF SMART SPECIALIZATION OF ECONOMY OF LVIV REGION

\begin{tabular}{|c|c|}
\hline Prerequisites & Priority sectors of the economy \\
\hline $\begin{array}{l}\text { - Availability of scientific and educational potential, } \\
\text { educational institutions and research institutions; } \\
\text { Availability of real potential of certain types of economic } \\
\text { activity; } \\
\text { - The competitiveness of these types of economic activity in } \\
\text { foreign markets; } \\
\text { - Active innovative activity of enterprises of certain groups of } \\
\text { industries; } \\
\text { - } \quad \text { Multiplier effect of job creation in other sectors. }\end{array}$ & $\begin{array}{l}\text { - Woodworking industry; } \\
\text { - Mechanical engineering, in particular the production of motor } \\
\text { vehicles, trailers and other vehicles and the production of } \\
\text { electrical equipment; } \\
\text { - } \quad \text { Manufacture of food products, beverages and tobacco; } \\
\text { - } \quad \text { Tourism activities; } \\
\text { - } \quad \text { Comufacture of basic pharmaceutical products; }\end{array}$ \\
\hline
\end{tabular}

Social trends in the development of Ukrainian regions, in particular the increasing demographic burden and population aging, have a significant impact on the choice of strategic goals for the socio-economic development of the regions. In these circumstances, long-term planning should take these trends into account and aim at ensuring social justice, that is, taking into account various aspects of human capital development and ensuring a decent living conditions.

\section{CONCLUSIONS}

The analysis of economic specialization of the region in terms of types of economic activity, its competitive advantages and features of innovation activity revealed the problems that arise in determining the strategic goals in the development of regional strategies using the concept of smart specialization. These problems are due to the lack of statistical and other analytical information for a thorough analysis of business activity in the region.

The biggest problem is the limitation of opportunities for assessing the innovative potential of the regions, which makes it impossible to formulate priorities for the development of smart specialization of the regional economy. In this context, the lack of information on existing patents, innovative developments carried out by regional institutions and which can be used in the real economy is negative.

The problem is the lack of effective links between the research and business sector of the regional economy, as well as the insufficient role of universities in shaping a regional innovation system that would become the basis for smart specialization. As a result of the analysis, scientists of the NAS of Ukraine have identified promising areas of economic and industrial activity, which can form the basis of the new Regional Development Strategy of the region, and become the basis for the development of the region on the basis of the potential of "smart economy".

Further studies on the smart specialization of Ukrainian regions may be conducted in order to study the activity of campaigns in which turnover or the number of personnel has increased by at least $5-7 \%$ over the last three years. Also critical to shaping the real smart specialization of the regions is deeper research into the sectors that shape human capital - medicine and recreation, sports, education and science. In addition, the scientific understanding of smart specialization at the regional level will be enhanced if we carry out brand studies that form the largest, structuring campaigns in the regions of Ukraine.

\section{REFERENCES}

[1] Order of the Ministry of Regional Development No. 373 of 27.12.2018 «On Amendments to the Order of the Ministry of Regional Development of Technological Development, Construction and Housing and Communal Services of Ukraine of March 31, 2016 No. 79»

[2] M. Benner, "Smart specialization and institutional context: the role of institutional discovery, change and leap frogging", European Planning Studies, 27 (9), pp. 1791-1810, 2019.

[3] J. Glückler and R. Lenz, "How institutions moderate the effectiveness of regional policy: A framework and research agenda", Investigaciones Regionales, (36Special issue), pp. 255-277, 2019.

[4] M. Benner, "From smart specialisation to smart experimentation. Building a new theoretical framework for regional policy of the European Union", Zeitschriftfur Wirtschafts geographie, 58(1), pp.33-49, 2014.

[5] H. Kroll, "Efforts to Implement Smart Specializationin PracticeLeading Unlike Horses to the Water", European Planning Studies, 23 (10), pp. 2079-2098, 2015.

[6] M. Sotarauta, "Smart specialization and place leadership: Dreaming about share dvisions, falling into policy traps?", Regional Studies, Regional Science, 5(1), pp.190-203, 2018.

[7] R. Ortega Argiles, P. McCann, I. Perianez-Forte, M. Cervantes, J. Larosse and L. Sanchez, "Innovation-driven growth in regions: the role of smart specialization", Paris: OECD/ODCE, p.202, 2013.

[8] D. D’Adda, E.Guzzini, D. Iacobucci and R. Palloni, "Is Smart Specialisation Strategy coherent with regional innovative capabilities?", Regional Studies, 53(7), pp.1004-1016, 2019.

[9] R. Capello and H. Kroll, "From theory to practice in smart specialization strategy: emerging limits and possibl efuture trajectories", European Planning Studies, 24(8), pp.1393-1406, 2016.

[10] P. Vallance, J. Blažek, J. Edwards and V.Květoň, "Smart specialisation in regions with less-developed research and innovation systems: A changing role for universities?", EnvironmentandPanning C: Politicsand Space, 36(2), pp.219-238, 2018.

[11] European Commission Smart Spesialisation Platform [Online]. Available: http://s3platform.jrc.ec.europa.eu/home.

[12] U. Andrusiv, O. Galtsova, "Evaluation of innovation activity of construction enterprises", Scientific bulletin of Polissia, 3 (11), pp. 204 - 215, 2017. doi: 0.25140/2410-9576-2017-1-3(11)-204-21. 